\title{
Ingenol Derivative LEO 43204 Gel
}

National Cancer Institute

\section{Source}

National Cancer Institute. Ingenol Derivative LEO 43204 Gel. NCI Thesaurus. Code C123379.

A topical, aqueous gel formulation containing a derivative of ing enol, a selective smallmolecule activator of protein kinase C (PKC) that is isolated from the sap of Euphorbia species, with the potential to treat preneoplastic skin lesions. Upon topical application of the ingenol derivative LEO 43204 gel, the agent presumably activates various PKC isoforms, which may induce apoptosis in abnormal cells found in severely sun-damaged skin with multiple actinic keratoses. This may decrease the number of actinic keratoses and prevent the development of skin neoplasms. The PKC family consists of signaling isoenzymes that regulate many cell processes, including proliferation, differentiation, and apoptosis. 